\title{
The Effect of Work Culture and Competitive Advantage on the Performance of Culinary and Service Companies During the COVID-19 Pandemic
}

\author{
Badzlina Balqis \\ Master of Management Student, Mercu Buana University \\ Jakarta, Indonesia
}

\begin{abstract}
This study aims to analyze the influence of work culture and competitive advantage on service and culinary companies during the COVID-19 pandemic. The research method used is the quantitative descriptive method and using a questionnaire with 65 respondents who have businesses in the service and culinary fields. The data obtained were processed using multiple linear regression methods with SPSS 16.0 application. The results showed that the variables of work culture and competitive advantage had significant importance on the performance of culinary and service companies during the COVID-19 pandemic.
\end{abstract}

Keywords:- Business Performance, Competitive Advantage, COVID-19, Work Culture.

\section{INTRODUCTION}

The COVID-19 outbreak to date has spread in various countries, including Indonesia. This virus first appeared in Wuhan, Hubei Province, China in December 2019 with a very rapid transmission rate and spread to almost all countries, including Indonesia, in just a few months. Increasing spread causes the World Health Organization (WHO) to set this outbreak to become a global pandemic after the number of infections worldwide reaches more than 121,000. The Indonesian government has also set this outbreak to be a national disaster, so it is recommended to the public to conduct social distancing in order to slow the spread of the virus. Besides, the government also recommends doing all activities from home.

The wide spread of the coronavirus has an impact on companies in Indonesia, including the service, $F \& B$, and retail segments. Impacts experienced by the company such as a decrease in revenue, a decrease in sales, difficulty in obtaining raw materials, hampered distribution, hampered production, changes in business strategy, and others. Many companies affected by the COVID-19 pandemic must reduce the number of employees to bankruptcy. The COVID-19 pandemic also caused companies in Indonesia to change their work culture. Several companies apply for work from home for their employees in completing their work. Some companies implement shifts in their working hours. Not a few employees were given additional work during the COVID-19 pandemic.

\author{
Setyo Riyanto \\ Associate Professor, Mercu Buana University \\ Jakarta, Indonesia
}

In addition to a change in work culture, during the COVID-19 outbreaks continued to look for ways to achieve competitive advantage compared to other products and companies that compete in the market. Companies offer higher value to consumers, either by offering lower prices or by providing more benefits to consumer services at higher prices. Based on the statement above, the author wants to analyze how much influence the work culture and competitive advantage has on the performance of the service and culinary companies during the COVID-19 pandemic.

\section{LITERATURE REVIEW}

\section{A. Work Culture}

Work culture is a habit that is repeated by employees in an organization. Violation of the habit does not have strict sanctions. However, morally the organization's actors have agreed that the habit is a habit that must be obeyed in order to carry out the work to achieve the goals (Nawawi, 2003) Work culture affects the organization in various ways, which means that with an increase in work culture, it will affect employee performance (Nugroho, 2011).

\section{B. Competitive Advantage}

Competitive advantage is a set of factors that distinguish a company from its competitors. The key to business success is the development of unique competitive advantages where excellence produces results that are difficult for competitors to imitate and value for customers (Adiputra, 2017). Competitive advantage is the core of performance in market competition because the competition is the core of success or failure of a company (Lasalewo, 2016). According to Respatya (2001), companies that produce products or services must pay attention to the concept of competitive advantage so that companies can survive that will ultimately make a profit. The competitive advantage consists of three dimensions, namely durability, the level of difficulty to be imitated, and the level of ease to match (Hall, 1990).

\section{Business Performance}

Business performance is the result of organizational goals achieved through the effectiveness of strategies and techniques (Fairoz, 2010). In the global era and during the COVID-19 pandemic, business performance has become an essential element for survival. Some factors that can determine business performance in an organization are creating customers by marketing, innovating, and economic 
productivity consisting of human resources, capital resources and physical resources. According to Wibowo (2008), performance as a result of work or work performance and how the work process takes place. Meanwhile, according to Armstrong and Baron in Wibowo (2008), performance is the result of work that has a relationship with the strategic objectives of the organization, customer satisfaction, and contribute to the economy.

\section{METHODOLOGY OF RESEARCH}

In this study, a quantitative approach is used to explain the influence between work culture variables $\left(\mathrm{X}_{1}\right)$ and competitive advantage $\left(\mathrm{X}_{2}\right)$ on business performance $(\mathrm{Y})$. The questionnaire was distributed to 65 respondents who had businesses in the service and culinary fields. Data analysis techniques used are as follows:

\section{A. Validity Test}

Validity test is used to test which question items are valid and which are invalid (Maida, 2017). Validity test in this study was conducted by comparing the value of $r$ arithmetic with $r$ table. If the value of $r$ count is higher than $r$ table, then the questionnaire items are valid.

\section{B. Reliability Test}

Reliability test is used to find out the question items used are reliable as a measurement tool. The method used in measuring the reliability of the questionnaire is by using Cronbach's Alpha method for each variable measured (Setiawan, 2016). Variables can be categorized as reliable if they have an alpha value higher than 0.60 (Riyanto, 2019).

\section{Multiple Linear Regression Analysis}

This analysis is used to determine the direction of the relationship between the dependent and independent variables, whether each independent variable is positive or negative. Besides this analysis is also used to predict the value of the dependent variable when there is an increase or decrease in the independent variable (Maida, 2017). The form of the multiple linear regression equation used is as follows:

$$
\begin{array}{ll}
\mathrm{Y}=\mathrm{a}+\mathrm{b}_{1} \mathrm{X}_{1}+\mathrm{b}_{2} \mathrm{X}_{2}+\mathrm{e} \\
\mathrm{Y} & =\text { Business Performance } \\
\mathrm{a} & =\text { Constant } \\
\mathrm{b}_{1} \ldots \mathrm{b}_{2} & =\text { Regression Coefficients } \\
\mathrm{X}_{1} & =\text { Work Culture } \\
\mathrm{X}_{2} & =\text { Competitive Advantage } \\
\mathrm{e} & =\text { Error }
\end{array}
$$

\section{Descriptive Analysis}

Descriptive analysis is used to analyze data by describing or describing data that has been collected so that the data presented can be easily understood and informative (Sholikhah, 2016). Descriptive hypotheses and statistical hypotheses can be arranged as follows.

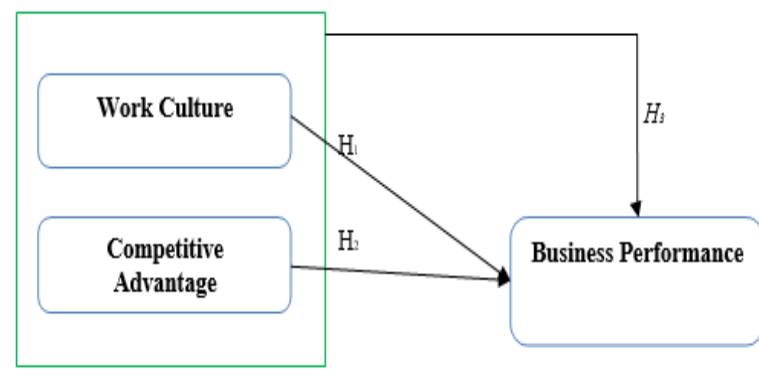

Fig 1:- Framework Model

\section{E. Hypothesis}

H1: Work culture affects business performance.

H2: Competitive advantage affects business performance.

H3: Work culture and competitive advantage affect business performance.

\section{RESULT AND DISCUSSION}

This research was conducted by distributing questionnaires to 65 respondents who have businesses in the service and culinary fields. The results obtained are processed using the SPSS 16.0 application for Windows. Characteristics of respondents are those who have businesses in the service and culinary fields and are seen from their age, gender, length of business, and also education. Descriptive analysis results showed that the majority of respondents were male and aged 21-30 years, with a percentage of 52\%. Respondents aged 31-40 years had a percentage of $23 \%$. Respondents aged 41-50 have a percentage of $12 \%$. Respondents who are more than 50 years old have a percentage of $11 \%$. The rest are respondents who are less than 20 years old. Besides, the majority of respondents have a minimum education level of $S 1$ and have been in business for two years. The questionnaire distributed consisted of 17 question items which were divided into three variables, namely work culture $\left(\mathrm{X}_{1}\right)$, competitive advantage $\left(\mathrm{X}_{2}\right)$ and business performance $(\mathrm{Y})$.

\section{A. Validity Test}

Validity test is used to test valid and invalid question items (Maida, 2017). In this study, the validity test is done by comparing the value of $r$ arithmetic with $r$ table. If the calculated $r$-value is higher than the $r$ table value, the questionnaire items are considered valid. The results of the validity test can be seen in the table below.

\begin{tabular}{|c|c|c|c|}
\hline Variable & $\mathbf{r}_{\text {count }}$ & $\mathbf{r}_{\text {table }}$ & Information \\
\hline $\begin{array}{c}\text { Work Culture } \\
\left(\mathrm{X}_{1}\right)\end{array}$ & $\begin{array}{c}0.495 \\
-\end{array}$ & 0.2441 & Valid \\
\hline $\begin{array}{c}0.728 \\
\text { Competitive }\end{array}$ & $\begin{array}{c}0.694 \\
-\end{array}$ & 0.2441 & Valid \\
Advantage $\left(\mathrm{X}_{2}\right)$ & 0.837 & & \\
\hline $\begin{array}{c}\text { Business } \\
\text { Performance } \\
(Y)\end{array}$ & $\begin{array}{c}0.762 \\
-\end{array}$ & 0.2441 & Valid \\
\hline
\end{tabular}

Table 1:- Validity Test On Work Culture $\left(\mathrm{X}_{1}\right)$, Competitive Advantage $\left(\mathrm{X}_{2}\right)$, And Business Performance (Y) 
Based on the above table, it can be seen that with a significance level of $5 \%$ the $r$ table value of 0.2441 is obtained. In the table, the validity test for the $\mathrm{X}_{1}$ variable which is a work culture variable shows that the variable has a calculated r-value of $0.495-0.728$ where the value is higher than the $r$ table value, so the $X_{1}$ variable is considered valid. Validity test for variable $\mathrm{X}_{2}$ which is a competitive advantage shows that the variable has a calculated $r$ value of $0.694-0.837$ where the value is higher than the value of $r$ table, so the $X_{2}$ variable is considered valid. Likewise, the validity test for the $\mathrm{Y}$ variable which is a business performance variable has a calculated r-value of 0.762 0.809 where the value is higher than the $r$ table value, so the $\mathrm{Y}$ variable is considered valid.

\section{B. Reliability Test}

Reliability test is used to show the level of internal consistency reliability by measuring the coefficient of Cronbach's Alpha where the variable can be categorized as reliable if it has an alpha value higher than 0.60 (Riyanto, 2019). The reliability test results based on the Cronbach's Alpha formula can be seen in the table below.

\begin{tabular}{|c|c|c|c|}
\hline Variable & $\begin{array}{c}\text { Reliability } \\
\text { Coefficient }\end{array}$ & $\begin{array}{c}\text { Critical } \\
\text { Point }\end{array}$ & Information \\
\hline $\begin{array}{c}\text { Work Culture } \\
\left(\mathrm{X}_{1}\right)\end{array}$ & 0.713 & 0.6 & Reliable \\
\hline $\begin{array}{c}\text { Competitive } \\
\text { Advantage }\left(\mathrm{X}_{2}\right)\end{array}$ & 0.871 & 0.6 & Reliable \\
\hline $\begin{array}{c}\text { Business } \\
\text { Performance }(\mathrm{Y})\end{array}$ & 0.807 & 0.6 & Reliable \\
\hline
\end{tabular}

Table 2:- The Result Of Reliability Test

Based on the above table, it can be seen that the variables of work culture $\left(\mathrm{X}_{1}\right)$, competitive advantage $\left(\mathrm{X}_{2}\right)$, and business performance (Y) have a coefficient value higher than 0.60 with the value of each variable of 0.713 for the work culture variable $\left(\mathrm{X}_{1}\right), 0.871$ for the variable competitive advantage $\left(\mathrm{X}_{2}\right)$, and 0.807 for business performance variables $(\mathrm{Y})$. From these results, the three variables can be said to be reliable.

\section{Multiple Linear Regression Analysis}

This analysis is used to determine the direction of the relationship between the dependent and independent variables, whether each independent variable is positive or negative. Besides this analysis is also used to predict the value of the dependent variable when there is an increase or decrease in the independent variable (Maida, 2017). The results of multiple linear regression analysis can be seen in the table below.

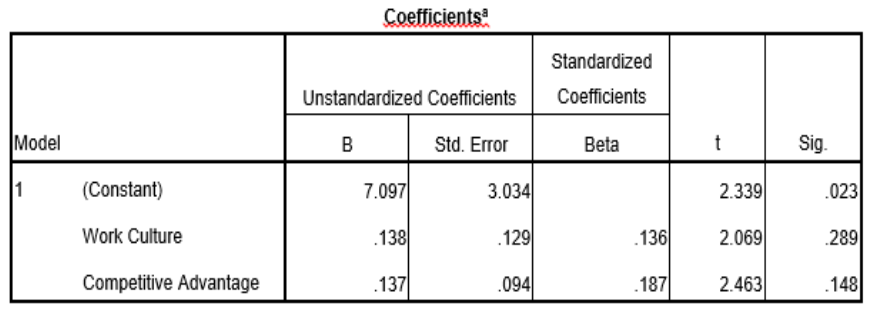

a. Dependent Variable: Business Performance

Table 3:- The Result Of Multiple Linear Regression Analysis

Based on the table above can be written into the form of multiple linear regression equations as follows:

$\mathrm{Y}=7.097+2.069 \mathrm{X}_{1}+2.463 \mathrm{X}_{2}$

Based on the above table, it can be seen that the work culture variable $\left(\mathrm{X}_{1}\right)$ has a calculated $t$ value of 2,069 with a $t$ table value of 1,999 . This shows that the variable $X_{1}$ has a significant effect on business performance because the calculated $t$ value is higher than the $t$ table value. Meanwhile, the competitive advantage variable $\left(\mathrm{X}_{2}\right)$ has a calculated $t$ value of 2,463 with a $t$ table value of 1,999 where it shows that the $\mathrm{X}_{2}$ variable has a significant effect on business performance because the calculated $t$ value is higher than the t table value.

\begin{tabular}{|ll|r|r|r|r|r|}
\hline \multicolumn{1}{|c|}{ ANQVA $^{\mathrm{b}}$} \\
\hline 1 & Sum of Squares & \multicolumn{1}{c|}{ df } & Mean Square & \multicolumn{1}{c|}{$\mathrm{F}$} & \multicolumn{1}{c|}{ Sig. } \\
\hline 1 & Regression & 65.932 & 2 & 32.966 & 9.237 & $.115^{\mathrm{a}}$ \\
& Residual & 913.853 & 62 & 14.740 & & \\
& Total & 979.785 & 64 & & & \\
\hline
\end{tabular}

a. Predictors: (Constant), Competitive Advantage, Work Culture

b. Dependent Variable: Business Performance

Table 4:- The Result Of F-Test

Based on the table above shows that the calculated $\mathrm{F}$ value obtained is 9,237 with a $F$ table value of 3.14. This shows that the variables of work culture and competitive advantage have a significant (simultaneous) effect on business performance variables because they have a calculated $F$ value higher than the $F$ table.

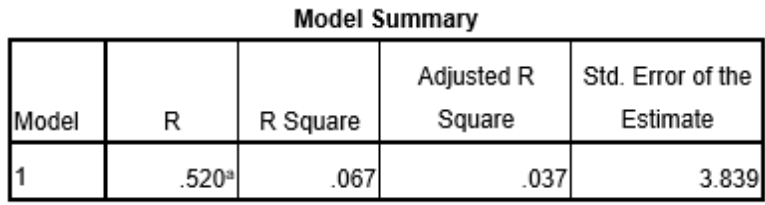

a. Predictors: (Constant), Competitive Advantage, Work Culture

Table 5:- The Result Of The Coeffiecient Of Determination

From the table above we can get the coefficient of determination as follows:

$$
\begin{aligned}
& \mathrm{KD}=\mathrm{R}^{2} \times 100 \% \\
& =(0.520)^{2} \times 100 \% \\
& =27 \%
\end{aligned}
$$


Based on the above calculations, it can be seen that the work culture variable $\left(\mathrm{X}_{1}\right)$ and competitive advantage $\left(\mathrm{X}_{2}\right)$ have a simultaneous influence of $27 \%$ on the business performance variable (Y). In comparison, the remaining $73 \%$ is influenced by other factors not examined in this study.

\section{CONCLUSION}

Based on the results of research and discussion that has been done, several conclusions can be drawn, including:

1. There is a positive and significant influence on work culture variables on business performance variables. This is evidenced by the acquisition of $t$ value of 2.069 , which is higher than the value of t table of 1.999 .

2. There is a positive and significant influence on the variable of competitive advantage on business performance variables. This is evidenced by the acquisition of $t$ value of 2,463 , which is higher than the value of $t$ table of 1,999 .

\section{REFERENCES}

[1]. Adiputra, I. P. P., \& Mandala, K. (2017). Pengaruh Kompetensi dan Kapabilitas Terhadap Keunggulan Kompetitif dan Kinerja Perusahaan. Jurnal Manajemen Unud, 6(11), 6090-6119.

[2]. Fairoz, et al. 2010. Entrepreneurial Orientation and Business Performance of Small and Medium Scale Enterprises of Hambantota District Sri Lanka. Asian Social Science Vol 6 No 3 March 2010.

[3]. Hall et al. 1990. Understanding Cultural Differences: Germans, French, and Americans. Intercultural Press.

[4]. Lasalewo, Trifandi. 2016. The Effect of Competitive Advantage and Human Advantage on Industrial Competitive Strategy (Case Study: SMIs in Gorontalo Province). Journal of Indonesian Economy and Business Vol. 31 No. 3.

[5]. Maida, M.T., Riyanto, S., dan Ali, H. 2017. Effect of Job Satisfaction and Leadership Style Towards Employee Productivity at PT Asuransi Umum Bumiputera Muda 1967. Saudi Journal of Business and Management Studies Vol-2: 157-168.

[6]. Nawawi, Hadari. 2003. Manajemen Sumber Daya Manusia Untuk Bisnis yang Kompetitif. Yogyakarta: Gadjah Mada University Press.

[7]. Nugroho, Agung, A., dan Djastuti, I. 2011. Pengaruh Kompensasi dan Budaya Kerja Terhadap Kinerja Karyawan pada PT. Pura Barutama Unit Offset Kudus. Undergraduate Thesis. Universitas Diponegoro.

[8]. Respatya dan Mulya. 2001. Analisa Pengaruh Strategi Pelayanan Prima dan Fasilitas Terhadap Kepuasan Nasabah Pada PT. Bank Negara Indonesia (Persek Kantor Cabang Semarang). Masters Thesis. Magister Manajemen Universitas Diponegoro.

[9]. Riyanto, Setyo. 2019. The Impact of Leadership, Organizational Culture and Organizational Climate on Employee Job Satisfaction. Advances in Economics, Business, and Management Research vol. 120.
[10]. Setiawan, Z dan Rusdiansyah. 2016. Peranan Bauran Harga Terhadap Peningkatan Penjualan Alat Kesehatan. Jurnal Pilar Nusa Mandiri Vol 12 No 2.

[11]. Sholikhah, A. 2016. Statistik Deskriptif Dalam Penelitian Kualitatif. Komunika Vol. 10 No. 2, JuliDesember 2016.

[12]. Wibowo, Amin. 2008. The Impact of Organisational Culture and Internal Corporate Governance on Organisational Performance in Indonesian Companies. Curtin University. 